\title{
Gender implications in sex education, knowledge, and vulnerability to sexually transmitted infections of healthcare students
}

\author{
Implicações do gênero na educação sexual, conhecimento e vulnerabilidade às infecções \\ sexualmente transmissíveis de acadêmicos de saúde
}

Implicaciones de género en la educación sexual, conocimiento y vulnerabilidad a las infecciones sexualmente transmisibles de académicos de sanidad

\begin{abstract}
The challenges posed by the implementation of sex education within a social context, by teachers or parents, are impasses that compromise adolescents' and young adults' sexual health, resulting in sexual risk behaviors. This study evaluated the forms of sex education, knowledge about sexually transmitted infections, and the vulnerability of university students within the Brazilian Legal Amazon. A total of 149 healthcare students provided their sociodemographic data and how they obtain information about safe sex practices. The data collected were evaluated using the Sexually Transmitted Disease Knowledge Questionnaire (STD-KQ) questionnaire. Bivariate analyses and Pearson correlation were performed. The sources of sex education were primarily accessed by students approaching course completion and female students nearing graduation, through teachers, specialized books, media, and friends. In general, men were found to have a higher degree of knowledge about STIs, while women reported feeling less protected sexually. Time spent at the university and the knowledge men possess were not found to reduce risky behavior. This cross-sectional study confirms that interventions to combat misinformation in the face of risky sexual behaviors and their consequences should be prioritized and should consider the gender of individuals and all the differences in the perceptions and actions of both male and female healthcare students.
\end{abstract}

Keywords: Sex Education; Knowledge; Sexual health; Sexually Transmitted Infections; University.

\begin{abstract}
Resumo
Os desafios impostos na implementação da educação sexual nos ambientes sociais, incluindo os escolares e parentais, são impasses que comprometem a saúde sexual dos adolescentes e adultos jovens, implicando nos comportamentos de risco. Este estudo avaliou os meios de educação sexual, o conhecimento sobre infecções sexualmente transmissíveis e a vulnerabilidade de universitários pertencentes à Amazônia Legal brasileira. Cento e quarenta e nove estudantes da área de saúde reportaram seus dados sociodemográficos e os meios de informação sobre sexo seguro e sua prática. $\mathrm{O}$ conhecimento foi avaliado por meio do questionário Conhecimento sobre as Doenças Sexualmente Transmissíveis (STD-KQ). Análises bivariadas e correlação de Pearson foram realizadas. Professores, livros especializados, mídia e amigos foram as fontes de informação sexual mais acessadas por estudantes em fase de conclusão de curso e mulheres em finalização da graduação. Homens apresentaram maior grau de conhecimento sobre IST. Mulheres reportaram
\end{abstract}

${ }^{1}$ These authors contributed equally to this work. 
uma menor possibilidade de proteção sexual. O tempo na universidade e conhecimento dos homens não interfere positivamente no comportamento de risco. Esse estudo transversal demonstra que as intervenções no combate à desinformação em face dos comportamentos sexuais de risco e suas consequências devem ser priorizadas considerando os gêneros dos indivíduos, tendo em vista as diferenças nas percepções e ações de homens e mulheres estudantes da área de saúde.

Palavras-chave: Educação Sexual; Conhecimento; Saúde sexual; Infecções Sexualmente Transmissíveis; Universidade.

\section{Resumen}

Los desafíos impuestos en la implementación de la educación sexual en los contextos sociales, incluyendo los escolares y parentales, son dificultades que ponen en riesgo la salud sexual de los adolescentes y adultos jóvenes, implicando en los comportamientos de riesgo. Este estudio evaluó los medios de educación sexual, o conocimiento sobre infecciones sexualmente transmisibles y la vulnerabilidad de universitarios pertenecientes a Amazonia Legal brasileña. Ciento cuarenta y nueve estudiantes del área de sanidad atribuyeron sus datos sociodemográficos y los medios de información sobre sexo seguro y su práctica. El conocimiento fue evaluado por medio de Cuestionario de Conocimiento sobre las Enfermedades de Transmisión Sexuales (STD-KQ). Análisis bivariados y correlación de Pearson han sido realizadas. Profesores, libros especializados, media y amigos fueron las fuentes de información sexual más accedidas por estudiantes en fase de conclusión de curso y mujeres en la finalización de la graduación. Hombres presentan mayor grado de conocimiento sobre Enfermedad sexualmente transmisible EST. Mujeres atribuyeron una menor posibilidad de protección sobre infección de transmisión sexual. El tiempo en la universidad y conocimiento de los hombres no impide positivamente en el comportamiento de riesgo. Ese estudio transversal demuestra que las intervenciones en el combate a la desinformación en faz de los comportamientos sexuales de riesgo y sus consecuencias deben ser priorizadas considerando los géneros de los individuos, llevando en cuenta las diferencias en las percepciones y acciones de hombres y mujeres estudiantes del área de sanidad.

Palabras clave: Educación Sexual; Conocimiento; Salud sexual; Enfermedades Sexualmente Transmisibles; Universidad.

\section{Introduction}

Sexually Transmitted Infections (STIs) are considerable impasses in health systems and are among the most pressing issues in the world today. The number of cases of gonorrhea, syphilis, and chlamydia have increased substantially since the 1970s (Williamson \& Chen, 2020). The challenges posed by STIs in terms of morbidity and resistance to therapy, among other things, adds to the difficulty of controlling them through appropriate treatment and lack of provision of health services for diagnosis, which ultimately hinders the introduction of suitable methods of protection to the community, vaccination in primary care and stimuli to educational policies (Unemo et al., 2017; Mohammed et al., 2018).

Irregular use of condoms, multiple sexual partnerships, sexual intercourse under the influence of alcohol or drugs, and early sexual activity constitute risk behaviors that increase the likelihood of infection and unintended pregnancy (Amare et al., 2019; Spindola et al 2019). Such behaviors are prevalent among adolescents and young adults in university, especially in relation to inconsistent use of condoms (Pimentel et al, 2016; Sales et al, 2016; Palacios-Delgado \& Ortego-Garcia, 2018; Kassie et al, 2019). The reasons identified for such conduct include social acceptance, difficulty negotiating the use of a condom with one's respective partner, association of using condoms with infidelity, and the perceived loss of pleasure due its use (Mthembu et al., 2019). Although many understand the associated risks are aware of safe sex practices, in practice, they do not apply this knowledge due to the belief of self-control (Xu et al., 2019).

The school environment is a space for mutual, collective, and interdisciplinary exchange between teachers and students. The socialization role of school facilitates change through challenging and reflecting on students' daily practices, which helps reinforce the health-disease process and normality-pathology. Freirean pedagogy is an effective means of support for carrying out health education activities on sexuality and STI prevention, enabling subjects to properly recognize and reflect on their actions in relation to sexual behavior risk (Beserra et a.1, 2011; Gava \& Vilela, 2016). This transformative educational role in reducing vulnerability was observed by Lindskog and Durevall (2020) who reported the positive impact of educational reform in reducing human immunodeficiency virus (HIV) infections among young adults during their first sexual intercourse 
or early pregnancy. Students who received formal education on how to refuse sex were less vulnerable to sexual assault upon entering university (Santanelli et al., 2018). In addition, family participation in sex education policies could help protect young people from potential risks once they start becoming sexually active (Grossman et al., 2014).

On the other hand, the shortcomings of formal education in relation to reproductive and sexual health limit students' knowledge about sexuality and vulnerability, resulting in the inconsistent use of condoms during sexual intercourse (Silva et al, 2002) which compromises the safety of the individual and his/her respective sexual partner. Taboos, beliefs, and myths could hinder a pedagogy of liberation and autonomy when the subject of sexuality is, often considered by the school community as non-school, non-political, and non-ideological content, creating a highly conservative learning environment (Zanatta et al., 2016).

The difficulties in the implementation and practice of sex education as a cross-sectional subject across academic year levels emphasizes the need for the University to act as a training institution for future professionals who are committed to the humanization and socialization of knowledge. The omission or marginalization of the discussion of human sexuality meets the need for students who belong to an age group that is susceptible to risky sexual behaviors to become more educated and selfaware. In this context, medical and nursing students have realized that knowledge about sexuality in the university environment is necessary to explore the different stages of an individual's life and to identify the potential consequences of diseases (Figueiroa et al., 2017; Komlenac et al., 2019) to be able to properly carry out self-care (Petry et al., 2019). On the other hand, the lack of attention to this subject in academic education could compromise professional actions, resulting in the asexualization of care, impersonality of relationships, lack of dialogue, or rising constraints (Sehnem et al., 2014).

In Brazil, university students' risky sexual behavior and knowledge about STIs have been reported by several groups (Fonte et al., 2018; Nascimento et al., 2018; Spindola et al., 2020), since they can still get STIs despite having increased access to information about sexual health (Teixeira et al, 2019). Therefore, the analysis of the approach to sex education prior to entry into the academic environment and during university education and its association with knowledge about STIs must be highlighted because it provides an opportunity to determine which measures of health education are necessary to avoid possible sexual health risks and promotes the implementation of this subject in the various undergraduate year levels as an act of humanization of health issues. Based on these aforementioned aspects, this study sought to evaluate students' knowledge about STIs while considering their sexual education throughout their academic life and overlooking their vulnerability.

\section{Methodology}

\section{Research design}

This is a descriptive, cross-sectional, and quantitative study that examines the knowledge of undergraduate healthcare students during their first and last year about STIs. Data were collected from November 2019 to March 2020 through a selfcompleted and anonymous survey, which was used to obtain the variables of interest. The ballot machine technique was used to ensure the confidentiality of the responses in order to improve the reliability of answers to socially controversial questions. Participants were informed that they could skip questions they did not feel comfortable answering. Further details regarding participants, procedures, measurements, and statistical analyses are presented below:

\section{Participants}

For convenience, university students from the Federal University of Tocantins (UFT), Palmas, Brazil were chosen as the research subjects. A booth was set up in the areas next to the Nursing, Medicine, and Nutrition buildings to recruit students. Subsequently, 170 men and women aged 18 years and above were invited. Among the recruits, 9 (5.29\%) chose not to 
participate in the study. A total of 161 participants answered the survey, 12 (7.45\%) of which were discarded due to incomplete or erroneous form completion. Ultimately, 149 responses were deemed valid for analysis.

\section{Procedures}

The research methodology was approved by the Research Ethics Committee of the UFT (CAAE: 22138619.2.0000.5519). The participants voluntarily signed an informed consent form after being informed about the study objectives. No compensation was offered for their participation.

\section{Measurements}

Participants were asked about their age, gender, sexual orientation, family income, and whether they were junior or senior students. The age of the participants was categorized into three groups: adolescents (18-19 years), young adults (20-24 years), and adults (> 24 years).

The "Questionnaire on Knowledge of Sexually Transmitted Diseases - (STD-KQ)" was used to evaluate the participants' understanding of Acquired Immunodeficiency Syndrome (AIDS), Human Immunodeficiency Virus (HIV), Hepatitis B, Human Papillomavirus (HPV), Genital Herpes, Chlamydia, and gonorrhea (Jaworski \& Carey, 2007). The questionnaire was adapted according to the particularities of each population evaluated (Saad et al, 2012; Pourmazi \& Sharami, 2017). This study used the STD-KQ recently validated in Brazil by Teixeira and collaborators (Teixeira et al., 2015; Teixeira et al., 2019). The questionnaire consists of 23 questions, which are answerable by "true," "false," or "I don't know."

Students' sources of information about safe sex included the following: parents, other family members, media (e.g., television, radio, newspapers), sexual partner, colleague/friend, the Internet, teachers, health professionals, religious community (e.g., pastor, shepherd, religious group), and specialized books. To assess the students' vulnerability, unprotected sex during their last sexual encounter was considered as risky sexual behavior.

\section{Statistical analysis}

Data were analyzed using descriptive statistics in SPSS Statistics 25 (IBM Corp., Armonk, NY, USA). Categorical variables were expressed as relative and absolute frequencies. Chi-square and Fisher's Exact were performed to explore the association between sex and sociodemographic variables. The same tests were used to verify the association between risky sexual behavior, sex education, and other variables. The respondents' level of knowledge was according to the method proposed by Weaver (Weaver, 2015) who classified the number of correct answers as low (0-9), moderate (10-18), and high (>18). The correlation between protected sex and the year level, STD-KQ, and sex education of the students were examined using Pearson's correlation coefficient. In all the analyses, p was considered statistical when $<0.05$.

\section{Results}

As presented in Table 1, the population consisted of 87 (58.4\%) female participants and $62(41.6 \%)$ male participants. The predominant age group was 20-24 years (50.3\%), highlighting the 18-19 year age group for female students (p=0.004). In terms of sexual orientation, majority reported being heterosexual. Out of the 149 participants, 92 (61.7\%) reported an income above 3 minimum wages. Among the participants whose family has an income of up to 3 minimum wages, there were 2.8 times more female participants $(\mathrm{p}=0.003)$ compared to males. In the analysis, $98(65.8 \%)$ participants were in the first year, and $51(34.2 \%)$ were seniors (Table 1$)$. 
Table 1. Sociodemographic characteristics of healthcare students, n (\%).

\begin{tabular}{|c|c|c|c|c|c|}
\hline & & & Sex & & \\
\hline & & $\begin{array}{l}\text { Total } \\
(n=149)\end{array}$ & Male $(n=62)$ & Female $(n=87)$ & $\mathbf{p}$ \\
\hline Age Group & $18-19$ & $48(32.2)$ & $11(17.7)$ & $37(42.5)$ & 0.004 \\
\hline & $20-24$ & $75(50.3)$ & $36(58.1)$ & $39(44.8)$ & \\
\hline & $>24$ & $26(17.4)$ & $15(24.2)$ & $11(12.6)$ & \\
\hline & Heterosexual & $132(88.6)$ & $52(83.9)$ & $80(91.5)$ & \\
\hline Sexual Orientation & Homosexual & $5(3.4)$ & $4(6.4)$ & $1(1.1)$ & $0.192 *$ \\
\hline & Bisexual & $12(8.0)$ & $6(9.7)$ & $6(6.9)$ & \\
\hline Family Income & Up to 3 & $57(38.3)$ & $15(24.2)$ & $42(48.3)$ & 0.003 \\
\hline & $>3$ & $92(61.7)$ & $47(75.8)$ & $45(51.7)$ & \\
\hline Year Level & Junior & $98(65.8)$ & $32(51.6)$ & $66(75.9)$ & 0.002 \\
\hline & Senior & $51(34.2)$ & $30(48.4)$ & $21(24.1)$ & \\
\hline
\end{tabular}

*Fisher test. Source: Prepared by the authors.

Accordingly, their means of obtaining information about how to practice safe sex were investigated considering their sex and year level (Table 2). The number of sources of sexual health information did not differ across gender, and there was no difference in access to the aforementioned sources regardless of year level (3.56 \pm 1.64 vs. $3.77 \pm 1.64)$. The number of sources of sexual health information of women in their senior year was higher than those in their junior year $(3.18 \pm 1.82 v s$. $5.33 \pm 2.71 ; \mathrm{p}<0,01)$. Women who were nearing graduation generally obtained information through media, colleagues/friends, and specialized books $(\mathrm{p}<0.05)$, and most of them accessed sexual health information through teachers $(\mathrm{p}=0.025)$. Men approached their parents more than women did $(64.5 \%$ vs. $47.1 \% \mathrm{p}=0.036)$. The number of questions that students reported not knowing the answer to varied between sexes, with women being less knowledgeable $(4.23 \pm 3.69$ vs. $2.81 \pm 2.51$; $p=0.006)$. However, the association with year level indicated that beginners were more likely to answer "I do not know" ( $p<0.01$ ).

Table 2. Correlation between sources of sexual health information accessed by university students according to their year level $(n=149)$.

\begin{tabular}{llllll}
\hline Sex & Education/Information About Safe Sex & & Year level & & \\
& & & Junior & Senior & p \\
Fathers & No & $36(54.5)$ & $10(47.6)$ & 0.580 \\
& Yes & $30(45.5)$ & $11(52.4)$ & \\
Other Family & No & $59(89.4)$ & $15(71.4)$ & 0.074 \\
& Yes & $7(10.6)$ & $6(28.6)$ & \\
Media & No & $38(57.6)$ & $5(23.8)$ & 0.007 \\
& Yes & $28(42.4)$ & $16(76.2)$ & \\
Sexual Partner & No & $60(90.9)$ & $15(71.4)$ & 0.062 \\
& Yes & $6(9.1)$ & $6(28.6)$ & \\
\hline
\end{tabular}


Research, Society and Development, v. 10, n. 9, e56710918354, 2021

(CC BY 4.0) | ISSN 2525-3409 | DOI: http://dx.doi.org/10.33448/rsd-v10i9.18354

\begin{tabular}{|c|c|c|c|c|c|}
\hline \multirow[t]{12}{*}{ Female (87) } & \multirow[t]{2}{*}{ Colleagues/Friends } & No & $44(66.7)$ & $6(28.6)$ & \multirow[t]{2}{*}{0.002} \\
\hline & & Yes & $22(33.3)$ & $15(71.4)$ & \\
\hline & \multirow[t]{2}{*}{ Internet } & No & $30(45.5)$ & $6(28.6)$ & \multirow[t]{2}{*}{0.171} \\
\hline & & Yes & $36(54.5)$ & $15(71.4)$ & \\
\hline & \multirow[t]{2}{*}{ Professors } & No & $27(40.9)$ & $3(14.3)$ & \multirow[t]{2}{*}{0.025} \\
\hline & & Yes & $39(59.1)$ & $18(85.7)$ & \\
\hline & \multirow[t]{2}{*}{ Healthcare Professionals } & No & $33(50)$ & $10(47.6)$ & \multirow[t]{2}{*}{0.842} \\
\hline & & Yes & $33(50)$ & $11(52.4)$ & \\
\hline & \multirow[t]{2}{*}{ Religious Community } & No & $64(97)$ & $18(85.7)$ & \multirow[t]{2}{*}{0.088} \\
\hline & & Yes & $2(3)$ & $3(14.3)$ & \\
\hline & \multirow[t]{2}{*}{ Specialized Books } & No & $59(89.4)$ & $10(47.6)$ & \multirow[t]{2}{*}{$<0.001$} \\
\hline & & Yes & $7(10.6)$ & $11(52.4)$ & \\
\hline & \multirow[t]{2}{*}{ Parents } & No & $9(28.1)$ & $13(43.3)$ & \multirow[t]{2}{*}{0.211} \\
\hline & & Yes & $23(71.9)$ & $17(56.7)$ & \\
\hline & \multirow[t]{2}{*}{ Other Family } & No & $26(81.3)$ & $26(86.7)$ & \multirow[t]{2}{*}{0.562} \\
\hline & & Yes & $6(18.8)$ & $4(13.3)$ & \\
\hline & \multirow[t]{2}{*}{ Media } & No & $16(50)$ & $9(30)$ & \multirow[t]{2}{*}{0.109} \\
\hline & & Yes & $16(50)$ & $21(70)$ & \\
\hline & Sexual Partner & No & $26(81.3)$ & $26(86.7)$ & \multirow[t]{2}{*}{0.562} \\
\hline \multirow[t]{13}{*}{ Male (62) } & & Yes & $6(18.8)$ & $4(13.3)$ & \\
\hline & \multirow[t]{2}{*}{ Colleagues/Friends } & No & $21(65.6)$ & $19(63.3)$ & \multirow[t]{2}{*}{0.851} \\
\hline & & Yes & $11(34.4)$ & $11(36.7)$ & \\
\hline & \multirow[t]{2}{*}{ Internet } & No & $18(56.2)$ & $14(46.7)$ & \multirow[t]{2}{*}{0.450} \\
\hline & & Yes & $14(43.8)$ & $16(53.3)$ & \\
\hline & \multirow[t]{2}{*}{ Professors } & No & $11(34.4)$ & $8(26.7)$ & \multirow[t]{2}{*}{0.511} \\
\hline & & Yes & $21(65.6)$ & $22(73.3)$ & \\
\hline & \multirow[t]{2}{*}{ Healthcare Professionals } & No & $20(62.5)$ & $19(63.3)$ & \multirow[t]{2}{*}{0.946} \\
\hline & & Yes & $12(37.5)$ & $11(36.7)$ & \\
\hline & \multirow[t]{2}{*}{ Religious Community } & No & $29(90.6)$ & $30(100)$ & 0.238 \\
\hline & & Yes & $3(9.4)$ & - & \\
\hline & Specialized Books & No & $30(93.8)$ & $23(76.7)$ & 0.077 \\
\hline & & Yes & $2(6.3)$ & $7(23.3)$ & \\
\hline
\end{tabular}

Source: Prepared by the authors.

The subsequent objective was to evaluate students' knowledge about STIs through the STD-KQ questionnaire (Table 3 ). Accordingly, in terms of the level of knowledge, there was a predominance of moderate (53\%) and high scores (43\%). Men who were nearing graduation obtained higher scores, while juniors obtained moderate scores $(p<0.05)$. The same phenomenon was observed for women. However, the female juniors generally got low scores $(\mathrm{p}<0.05)$ (Table 3$)$. 
Table 3. Correlation between university students' knowledge about STIs, risky sexual behavior, and year level.

\begin{tabular}{|c|c|c|c|c|}
\hline \multirow[t]{3}{*}{ Sex } & \multirow[t]{2}{*}{ Degree of Knowledge $(n=149)$} & \multicolumn{3}{|c|}{ Year Level } \\
\hline & & Junior & Senior & $\mathbf{p}$ \\
\hline & Low & $5(7.6)$ & $1(4.8)$ & $0.009 *$ \\
\hline \multirow[t]{2}{*}{ Female (87) } & Moderate & $41(62.1)$ & $6(28.6)$ & \\
\hline & High & $20(30.3)$ & $14(66.7)$ & \\
\hline \multirow[t]{2}{*}{ Male (62) } & Moderate & $21(65.6)$ & $11(36.7)$ & 0.023 \\
\hline & High & $11(34.4)$ & $19(63.3)$ & \\
\hline \multicolumn{5}{|c|}{ Risky sexual behavior among university students $(\mathrm{n}=119)$} \\
\hline \multicolumn{5}{|c|}{ Did you use a condom the last time you engaged in sexual intercourse? } \\
\hline & No & $21(44.7)$ & $12(66.7)$ & 0.113 \\
\hline \multicolumn{5}{|l|}{ Female (65) } \\
\hline & Yes & $26(55.3)$ & $6(33.3)$ & \\
\hline & No & $5(17.9)$ & $16(61.5)$ & 0.001 \\
\hline \multicolumn{5}{|l|}{ Male (54) } \\
\hline & Yes & $23(82.1)$ & $10(38.5)$ & \\
\hline
\end{tabular}

*Fisher test. Source: Prepared by the authors.

In order to investigate vulnerability in relation to risky sexual behavior, participants were asked about their use of condoms during their last sexual encounter. Initially, those who reported not having an active sex life were disregarded. In effect, 119 participants were included in the analysis and $65(54.6 \%)$ reported using protection during sexual intercourse and $54(45.4 \%)$ did not use condoms. $63.6 \%$ of the students who were nearing graduation and $34.7 \%$ of those who were at the beginning of their academic life engaged in unprotected sex $(\mathrm{p}=0.002)$. Majority of men from the earlier year levels used condoms ( $\mathrm{p}<0.01)(\mathrm{CI} 95 \%$ : 1.42 - 4.45). For women, there was no association between year level and using protection (Table $3)$.

Based on the analysis of the association between year level and sex education and the degree of knowledge about STIs, considering the sex of the students, a correlation was established to determine whether such variables could be related to the practice of safe sex. For male students, Spearman's correlation showed that there was a negative correlation between the year level, number of questions answered in the STD-KQ, and practice of safe sex. No significant correlation was found among female participants (Table 4).

6

Table 4. Correlation between safe sex and year level, STD-QK, and sex education of healthcare students.

\begin{tabular}{llll}
\hline Sex & Variable & Correlation & p \\
\hline \multirow{2}{*}{ Female } & Year Level & -0.197 & 0.116 \\
& STD-QK & 0.012 & 0.927 \\
& Sex Education & 0.111 & 0.379 \\
\multirow{2}{*}{ Male } & Year Level & -0.448 & 0.001 \\
& STD-QK & -0.362 & 0.007 \\
& Sex Education & -0.151 & 0.277 \\
\hline
\end{tabular}

Source: Prepared by the authors. 


\section{Discussion}

In this study, access to sex education related to the practice of safe sex was mainly evident in the school environment through teachers and specialized books, as well as media and interpersonal relationships. Sources of information and sexual counseling vary between men and women. No differences in access to sex education were observed among men. Although adolescents and young women have better access to sexual health information through their parents, primarily their mothers, whom they can dialogue with about sexuality and sexual experiences (Measor, 2015), this study found that men were more included in the transmission of knowledge within their respective families. The study's results match with that of Isaksen and collaborators (Isaksen et al., 2020) who found that less than half of the girls had spoken with their parents about romantic and/or sexual issues, but that proximity through family connection was a key factor for obtaining information. Parents play a key role in deciding when their children begin engaging in sexual intercourse, impeding early sexual activity (França \& Frio, 2018). When sex education also comes from partners, parents, friends, and religious leaders, there is a greater chance of changes in one's perceptions and behaviors (Pinyaphong et a.1, 2018).

The students themselves wonder about lack of communication in the family regarding sexuality (Ew et al., 2017). Oftentimes, the difficulty in the approach, embarrassment about the subject, lack of interest in seeking further information, or lack of knowledge are factors that hinder parental intervention (Barbosa et al., 2008; Ramos et al., 2020). Although other information resources are available (e.g., school, media, and friends), the safest space where teenagers can expose their doubts, anguish, and ideas about this subject is still the family environment, which helps individuals form their own values and beliefs (Savegnago \& Arpini, 2016).

For Brant and Martins (Brant \& Martins, 2020), unmediated media access, which is part of daily life, could make young people vulnerable to STIs, since one of its effects is to promote early sex. Consequently, young people need to be careful about the appropriacy and safety of the content they are exposed to (Brant \& Martins, 2020).

Although the school is a conducive environment and a primary tool for the development of sex education (Tanton et al., 2015) because it is where students spend most of their time and because it is a place of information and training (Genz et al., 2017), young people consequently have few opportunities to discuss sex and end up receiving a superficial sex education, which consists of distorted information permeated by taboos and prejudice, and is insufficient for risk prevention (Ew et al., 2017). In the Brazilian territory, such initiatives are often temporary and implemented by professionals who do not belong to the school board (Furlanetto et al., 2018).

The present study found that healthcare students had sufficient knowledge about STIs. The average number of correct answers was higher compared to the first Brazilian study that validated the instrument (Teixeira et al, 2019). Unlike other studies (Fonte et al., 2018; Teixeira et al., 2019; Pereira \& Carmo, 2014), women ended up answering more questions than the men did. This could be attributed not only to the greater presence of women from the earlier year levels (75.9\%), but also by other variables beyond the scope of the study, including economic condition and age. These variables were directly proportional to the participants' degree of knowledge. In fact, although access to the university corresponds to access to knowledge in relation to the general population, the variables of poverty and unsafe living conditions could also have a greater impact on the vulnerability of these students.

In this study, it is worth highlighting the lack of knowledge about the signs, symptoms, and treatment for chlamydia, hepatitis B, HIV, and their correlation with HPV. In the academic context, the lack of attention given to sex education in the training of health professionals may compromise their care, dialogue, and self-confidence in their future service. The means of addressing this subject must go beyond t being a mere biological and scientific vision, and allow the subjects to discover their attitudes through an interactive bias, which could help them maintain their sexual health. 
Knowledge about risky sexual behaviors does not always result in the actual adoption of safe practices (Xu et al., 2019; Fonte et al., 2018; Tobin-West et al., 2014). This study's findings are similar to those of Folasayo et al. (Folasayo et al., 2017) who found the inadequate use of protection among most sexually active healthcare students who had moderate knowledge about STIs.

In this context, women had a 1.5 chance of engaging in risky sexual behavior in relation to men. Particularly among seniors, the number of respondents who indicated that they did not use condoms was relatively high. One explanation for this phenomenon is the persisting gender asymmetry in sexual relations wherein men still exert greater power in ultimately deciding whether or not to use a condom that impacts the sexual health of their partners. This patriarchal system still perpetuated in Brazilian society limits women's sexual freedom (Chacham et al., 2016; Tavares et al., 2020). Even though women are aware of STIs and have direct access to information about sexual health, behavior aimed at adopting adequate protection measures has not been properly taught (Olivi et al., 2008).

Gender stereotypes, which have existed in Brazilian society for centuries, contribute to the reinforcement of attitudes based on patterns and convictions about what it is to be male, and the role played by the sexes. Consequently, convinced of their invulnerability and perceiving STIs as a sign of weakness, men take less care of themselves and put themselves at risk, despite possessing sufficient knowledge. With respect to the effects of this stereotype on the role of women, women are judged more when it comes to the topic of sex, and are often criticized for owning a condom or when their partners do not use protection, resulting in female vulnerability (Nascimento et al., 2018; Santos et al., 2016). This cultural aspect of Brazil's monogamous and conservative society marginalizes individuals who carry condoms, judging them as infidels and/or being promiscuous. In light of this, men and women must be educated on how to recognize and be more respectful of their partners' desire to have a safe sexual relationship.

Interventions to combat misinformation in the face of risky sexual behaviors and their respective consequences should be prioritized in view of significant differences in the perceptions and actions of men and women. Although access to university is a means of acquiring knowledge, it must consider the social vulnerability of the young population. Finally, parental involvement in the school environment could promote the robust implementation of sex education in a longitudinal manner. In this context, such actions focused on the process of educating based on guiding documents and specific legislation beyond the technical-scientific aspect must respect the phases and cultural environment of each individual in order to minimize existing gaps.

The main limitation of this study is related to the sample size of the population. It should be noted that the study sought to recruit a larger number of participants. However, the original questionnaire design was originally carried out prior to the COVID-19 pandemic. Therefore, due to mandatory physical and social distancing, online application was not possible because it would allow the participants to access information, and this would affect their responses. In a way, the evidence of vulnerability despite having knowledge about STIs was evidenced in this study.

\section{Conclusion}

This study identified the vulnerability of healthcare university students in relation to sex, despite their acquisition of sexual education and knowledge about STIs. Women had more possibilities on sex education and were less likely to be sexually protected. Men had a higher level of knowledge about STIs and risky sexual behavior. The time integrated into the university environment favors the acquisition of knowledge, but not protective measures. School-led health promotion policies and interventions that promote sexual health have to encourage sexual assertiveness and reduce risky sexual practices within the young population that is very vulnerable to sexually transmitted infections. 
Research, Society and Development, v. 10, n. 9, e56710918354, 2021

(CC BY 4.0) | ISSN 2525-3409 | DOI: http://dx.doi.org/10.33448/rsd-v10i9.18354

\section{Acknowledgments}

The present work was carried out with the support of the Federal University of Tocantins (UFT). DJA was supported by the Scientific Initiation Program at the Federal University of Tocantins (PIBIC/UFT). The authors declare no conflict of interest.

\section{References}

Amare, T., Yeneabat, T., \& Amare, Y. (2019). A systematic review and meta-analysis of epidemiology of risky sexual behaviors in college and university students in Ethiopia, 2018. Journal of environmental and public health, 2019.

Barbosa, S. M., Costa, P. N. P., \& Vieira, N. F. C. (2008). Estágios de mudança dos pais nas conversas com os filhos sobre prevenção Hiv/Aids. Revista Latino-Americana de Enfermagem, 16(6), 1-7.

Brant, T. F., \& Martins, M. (2020). The sources of information influence sex education? dilemmas for the approach to sexuality in the initial formation of physical education teachers. Campo Abierto. Revista De Educación, 39(1), 43-54.

Beserra, E. P., Torres, C. A., Pinheiro, P. N. C., Alves, M. D. S., \& Barroso, M. G. T. (2011). Pedagogia freireana como método de prevenção de doenças. Ciência \& Saúde Coletiva, 16, 1563-1570.

Chacham, A. S., Simão, A. B., \& Caetano, A. J. (2016). Gender-based violence and sexual and reproductive health among low-income youth in three Brazilian cities. Reproductive Health Matters, 24(47), 141-152.

Figueiroa, M. N., de Menezes, M. L. N., Monteiro, E. M. L. M., de Andrade, Â. R. L., Fraga, D. P. F., \& de Oliveira, M. V. (2017). Nursing students' perception of training on human sexuality. Revista de Enfermagem Referência, 4(15), 21-30.

Ew, R. D. A. S., Conz, J., Farias, A. D. G. O., Sombrio, P. B. M., \& Rocha, K. B. (2017). Diálogos sobre sexualidade na escola: uma intervenção possível. Revista Psicologia em Pesquisa, 11(2), 51-60.

Fonte, V. R. F. D., Spindola, T., Francisco, M. T. R., Sodré, C. P., André, N. L. N. D. O., \& Pinheiro, C. D. (2018). Young university students and the knowledge about sexually transmitted infectionsa. Escola Anna Nery, 22.

Folasayo, A. T., Oluwasegun, A. J., Samsudin, S., Saudi, S. N. S., Osman, M., \& Hamat, R. A. (2017). Assessing the knowledge level, attitudes, risky behaviors and preventive practices on sexually transmitted diseases among university students as future healthcare providers in the central zone of Malaysia: a cross-sectional study. International Journal Environmental and Research Public Health, 14(2), 159.

França, M. T.A., \& Frio, G. S. (2018). Factors associated with family, school and behavioral characteristics on sexual initiation: A gender analysis for Brazilian adolescents. PloS one, 13(12), e0208542.

Furlanetto, M. F., Lauermann, F., Costa, C. B. D., \& Marin, A. H. (2018). Educação sexual em escolas brasileiras: revisão sistemática da literatura. Cadernos de Pesquisa, 48(168), 550-57.

Gava, T., \& Villela, W. V. (2016). Educação em Sexualidade: desafios políticos e práticos para a escola. Sexualidad, Salud y Sociedad (Rio de Janeiro), 157171.

Genz, N., Meincke, S. M. K., Carret, M. L.V., Corrêa, A. C. L., \& Alves, C. N. (2017). Doenças sexualmente transmissíveis: conhecimento e comportamento sexual de adolescentes. Texto \& Contexto Enfermagem, 26(2), e5100015.

Grossman, J. M., Tracy, A. J., Charmaraman, L., Ceder, I., \& Erkut, S. (2014). Protective effects of middle school comprehensive sex education with family involvement. Journal of School Health, 84(11), 739-747.

Isaksen, K. J., Musonda, P., \& Sandøy, I. F. (2020). Parent-child communication about sexual issues in Zambia: a cross sectional study of adolescent girls and their parents. BMC Public Health, 20(1), 1-12

Jaworski, B. C., \& Carey, M. P. (2007). Development and psychometric evaluation of a self-administered questionnaire to measure knowledge of sexually transmitted diseases. AIDS and Behavior, 11(4), 557-574.

Kassie, B. A., Yenus, H., Berhe, R., \& Kassahun, E. A. (2019). Prevalence of sexually transmitted infections and associated factors among the University of Gondar students, Northwest Ethiopia: a cross-sectional study. Reproductive health, 16(1), 1-8.

Komlenac, N., Siller, H., \& Hochleitner, M. (2019). Medical students indicate the need for increased sexuality education at an Austrian medical university. Sexual medicine, 7(3), 318-325.

Lindskog, A., \& Durevall, D. (2021). To educate a woman and to educate a man: Gender-specific sexual behavior and human immunodeficiency virus responses to an education reform in Botswana. Health economics, 30(3), 642-658.

Measor, L. (2004). Young people's views of sex education: gender, information and knowledge. Sex education, 4(2), $153-166$.

Mohammed, H., Blomquist, P., Ogaz, D., Duffell, S., Furegato, M., Checchi, M., Irvine, N., Wallace, L. A., Thornas, D. R., Nardone, A., Dunbar, J. K., \& Hughes, G. (2018). 100 years of STIs in the UK: a review of national surveillance data. Sexually transmitted infections, 94(8), 553-558. 
Research, Society and Development, v. 10, n. 9, e56710918354, 2021

(CC BY 4.0) | ISSN 2525-3409 | DOI: http://dx.doi.org/10.33448/rsd-v10i9.18354

Mthembu, Z., Maharaj, P., \& Rademeyer, S. (2019). "I am aware of the risks, I am not changing my behaviour": risky sexual behaviour of university students in a high-HIV context. African Journal of AIDS Research, 18(3), 244-253.

Nascimento, B. S., Spindola, T., Pimentel, M. R. A. R., de Almeida Ramos, R. C., Santana, R. S. C., \& Teixeira, R. S. (2018). Comportamento sexual de jovens universitários e o cuidado com a saúde sexual e reprodutiva. Enfermería Global, 17(1), 237-269.

Olivi, M., Santana, R. G., \& Mathias, T. A. F. (2008). Comportamento, conhecimento e percepção de risco sobre doenças sexualmente transmissíveis em um grupo de pessoas com 50 anos e mais de idade. Revista Latino-Americana de Enfermagem, 16(4), 679-685.

Palacios-Delgado, J. R., \& Ortego-García, N. (2020). Diferencias en los estilos de negociación sexual y autoeficacia en el uso del condón en hombres y mujeres universitarios de Querétaro, México, 2018. Revista Colombiana de Obstetricia y Ginecología, 71(1), 9-20.

Pereira, H., \& Carmo, A. (2014). Sexually transmitted diseases: knowledge and perceived prevalence of symptoms in university students. International STD Research \& Reviews, 2(1), 01-11.

Petry, S., Padilha, M. I., Kuhnen, A. E., \& Meirelles, B. H. S. (2019). Saberes de estudantes de enfermagem sobre a prevenção de Infecções Sexualmente Transmissíveis. Revista Brasileira de Enfermagem, 72, 1145-1152.

Pimentel, M. H., Preto, L. S. R., Alves, M. J. G., \& Monteiro, A. M. P. (2016). Comportamento sexual e estudantes do ensino superior. Psicologia, Saúde e Doenças, 17(3), 352-367.

Pinyaphong, J., Srithanaviboonchai, K., Chariyalertsak, S., Phornphibul, P., Tangmunkongvorakul, A., \& Musumari, P. M. (2018). Inconsistent condom use among male university students in Northern Thailand. Asia Pacific Journal Public Health, 30(2), 147-157.

Pourmarzi, D., \& Sharami, S. H. (2017). Midwives' educational needs and knowledge about sexually transmittable infections in the Islamic Republic of Iran. East Mediterr Health J, 23(9), 611-8.

Ramos, M. S., Barbosa, A. A., Ribamar, W. M., \& Araújo, A. S. (2020). Visão do sexo masculino sobre os métodos e prevenção das infecções sexualmente transmissíveis. Cadernos da FUCAMP, 19(40), 70-89.

Saad, A., Rampal, L., Sabitu, K., AbdulRahman, H., Awaisu, A., AbuSamah, B., \& Ibrahim, A. (2012). Impact of a customized peer-facilitators training program related to sexual health intervention. International health, 4(4), 277-282.

Sales, W. B., Caveião, C., Visentin, A., Mocelin, D., da Costa, P. M., \& Simm, E. B. (2016). Comportamento sexual de risco e conhecimento sobre IST/SIDA em universitários da saúde. Revista de enfermagem referência, 4(10), 19-27.

Santelli, J. S., Grilo, S. A., Choo, T. H., Diaz, G., Walsh, K., Wall, M., Hirsch, J. S., Wilson, P. A, Gilbert, L., Khan, S., \& Mellins, C. A. (2018). Does sex education before college protect students from sexual assault in college?. PloS one, 13(11), e0205951.

Santos, C. P., Barboza, E. C. S., Freitas, N. O., Almeida, J. C., Dias, A. C., \& Araújo, E. C. (2016). Adesão ao uso do preservativo masculino por adolescentes escolares. Revista Brasileira de Pesquisa em Saúde, 18(2), 60-70.

Savegnago, S. D. O., \& Arpini, D. M. (2016). A abordagem do tema sexualidade no contexto familiar: o ponto de vista de mães de adolescentes. Psicologia Ciência e Profissão, 36(1), 130-144.

Sehnem, G. D., Pedro, E. N. R., Budó, M. D. L. D., DA SILVA, F. M., \& Ressel, L. B. (2014). A construção da sexualidade de estudantes de enfermagem e suas percepções acerca da temática. Ciencia y Enfermería, 20(1), 111-121.

Silva, W. A., Buchalla, C. M., Paiva, V., Latorre, M. D. R. D. D. O., Stall, R., \& Hearst, N. (2002). Prevenção de doenças sexualmente transmissíveis e Aids entre jogadores juniores. Revista de Saúde Pública, 36, 68-75.

Spindola, T., Araújo, A. S. D. B. D., Brochado, E. D. J., Marinho, D. F. S., Martins, E. R. C., \& Pereira, T. D. S. (2020). Prácticas sexuales y comportamiento de jóvenes universitarios frente a la prevención de infecciones de transmisión sexual. Enfermería Global, 19(58), 109-140.

Spindola, T., Oliveira, C. S. R., Santana, R. S. C., Sodré, C. P., de Oliveira André, N. L. N., \& de Jesus Brochado, E. (2019). Sexual Practices, Knowledge and Behavior of College Students Regarding Sexually Transmitted Diseases/Práticas Sexuais, Conhecimento e Comportamento dos Universitários em Relação às Infecções Sexualmente Transmissíveis. Revista de Pesquisa Cuidado é Fundamental Online, 11(5), 1135-1141.

Tanton, C., Jones, K. G., Macdowall, W., Clifton, S., Mitchell, K. R., Datta, J., Lewis, R., Field, N., Sonnenberg, P., Stevens, A., Wellings, K., Johnson, A. M., \& Mercer, C. H. (2015). Patterns and trends in sources of information about sex among young people in Britain: evidence from three National Surveys of Sexual Attitudes and Lifestyles. BMJ open, 5(3), 30-30.

Tavares, M. K. B., Melo, R. L., Rocha, B. F. D., Andrade, D. J., Evangelista, D. R., Peres, M. C., Baldaçara, L. R., Vieira, T. D. S., Assis, E. V., \& Silva, J. B. N. F. (2020). Dating Applications, Sexual Behaviors, and Attitudes of College Students in Brazil's Legal Amazon. International Journal of Environmental Research Public Health, 17(20), 7494.

Teixeira, L. O., Figueiredo, V. L. M. D., Gonçalves, C. V., \& Mendoza-Sassi, R. A. (2019). Avaliação Psicométrica da versão brasileira do "Questionário sobre Conhecimento de Doenças Sexualmente Transmissíveis". Ciência \& Saúde Coletiva, 24, 3469-3482.

Teixeira, L. O., Figueiredo, V. L. M., \& Mendoza-Sassi, R. A. (2015). Adaptação transcultural do Questionário sobre Conhecimento de Doenças Sexualmente Transmissíveis para o português brasileiro. Jornal Brasileiro de Psiquiatria, 64, 247-256.

Tobin-West, C. I., Maduka, O., Onyekwere, V. N., \& Tella, A. O. (2014). Awareness, acceptability, and use of female condoms among university students in Nigeria: implications for STI/HIV prevention. International Journal Adolescent Medicine Health, 26(2), 259-265. 
Research, Society and Development, v. 10, n. 9, e56710918354, 2021

(CC BY 4.0) | ISSN 2525-3409 | DOI: http://dx.doi.org/10.33448/rsd-v10i9.18354

Unemo, M., Bradshaw, C. S., Hocking, J. S., de Vries, H. J., Francis, S. C., Mabey, D., Marrazzo, J. M., Sonder, G. J. B., Schwebke, J. R., Hoornenborg, E., Peeling, R. W., Philip, S. S., Low, N., \& Fairley, C. K. (2017). Sexually transmitted infections: challenges ahead. The Lancet infectious diseases, 17(8), e235e279.

Weaver, R. D. (2015). An assessment of sexually transmitted disease knowledge among 7th grade students. [dissertation]. Minneapolis (MN): Walden University.

Williamson, D. A., \& Chen, M. Y. (2020). Emerging and reemerging sexually transmitted infections. New England Journal of Medicine, 382(21), $2023-2032$.

Xu, H., Xie, J., Xiao, Z., Xiao, H., Li, X., Goldsamt, L., Willians, A. B., \& Wang, H. (2019). Sexual attitudes, sexual behaviors, and use of HIV prevention services among male undergraduate students in Hunan, China: a cross-sectional survey. BMC Public Health, 19(1), 250.

Zanatta, L. F., Moraes, S. P. D., Freitas, M. J. D. D., \& Brêtas, J. R. D. S. (2016). A educação em sexualidade na escola itinerante do MST: percepç̃es dos (as) educandos (as) I. Educação e pesquisa, 42, 443-458. 